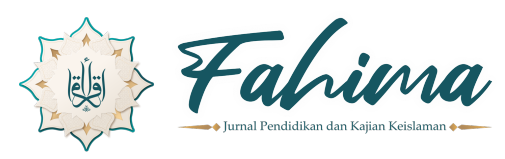

Fahima: Jurnal Pendidikan dan Kajian Keislaman

E-ISSN: 2808-4349 | P-ISSN: 2808-747X | Volume 1 No. 1 Januari 2022

\title{
PENGARUH STRATEGI PEMBELAJARAN BERBASIS E- LEARNING DAN MOTIVASI BELAJAR TERHADAP PRESTASI MATA PELAJARAN SEJARAH KEBUDAYAAN ISLAM (SKI)
}

\author{
Sri Mulyati ${ }^{*}$, Khoiruddin Nasution ${ }^{2}$ \\ ${ }^{1}$ MTs Ma'arif Gesi Sragen, Indonesia. \\ 2 UIN Sunan Kalijaga Yogyakarta, Indonesia. \\ *Surel Penulis Koresponden: srimulyati978@gmail.com
}

\begin{tabular}{|l|l|l|l|}
\hline \multicolumn{4}{|c|}{ Riwayat Artikel: } \\
\hline Dikirim: 28/10/2021 & Ditinjau: 29/10/2021 & Diperbaiki: 27/12/2021 & Diterima: 6/1/2022 \\
\hline
\end{tabular}

\begin{abstract}
Abstrak
Tujuan dari penelitian ini adalab 1) untuk mengetabui pengarub strategi pembelajaran e-learning terhadap prestasi mata pelajaran SKI ; 2) untuk mengetahui pengarub motivasi belajar terhadap prestasi mata pelajaran SKI; 3) untuk mengetabui pengaruh strategi pembelajaran berbasis e-learning dan motivasi belajar terhadap prestasi mata pelajaran SKI.

Penelitian menggunakan pendekatan kuantitatif dengan populasi 78 siswa. Data diambil melalui angket dengan uji validitas dan reliabitas. Data penelitian dianalisis dengan teknik regresi berganda. Objek penelitian adalah siswa MA NU Gesi Sragen tabun pelajaran 2020/2021.

Hasil penelitian menunjukekan babwa strategi pembelajaran berbasis e-learning dan motivasi belajar memberikan pengaruh positif pada prestasi belajar siswa di mata pelajaran SKI siswa MA NU Gesi Sragen tabun pelajaran 2020/2021.
\end{abstract}

Kata Kunci: e-learning, motivasi belajar, prestasi mata pelajaran

\begin{abstract}
The purposes of this study are 1) to determine the effect of e-learning learning strategies on the achievement of SKI subjects; 2) to determine the effect of learning motivation on the achievement of SKI subjects; 3) to determine the effect of e-learning based learning strategies and learning motivation on the achievement of SKI subjects.

The study used a quantitative approach with a population of 78 students. Data were taken through a questionnaire with validity and reliability tests. Multiple regression techniques analyzed the research data. The research object is MA NU Gesi Sragen students for the 2020/2021 academic year.
\end{abstract}


The results showed that e-learning-based learning strategies and learning motivation positively influenced student achievement in SKI subjects for MA NU Gesi Sragen students in the academic year 2020/2021.

Keywords: e-learning, learning motivation, learning achievement

\section{A. PENDAHULUAN}

Pendidikan pada dasarnya merupakan usaha sadar untuk menciptakan manusia seutuhnya, dalam arti manusia yang dapat membangun dirinya sendiri dan secara bersama-sama membangun bangsa dan negara. Hal ini seperti yang tercantum dalam Sisdiknas No.20 pasal 3 Tahun 2003 bahwa "Pendidikan Nasional bertujuan untuk berkembangnya potensi peserta didik agar menjadi manusia yang beriman, bertaqwa kepada Tuhan Yang Maha Esa, berakhlak mulia, sehat, berilmu, cakap, kreatif, mandiri dan menjadi warga negara yang demokratis serta bertanggung jawab. Maka dari itu penyelenggaraan pendidikan di sekolah perlu terencana untuk mewujudkan suasana belajar dan proses pembelajaran agar siswa secara aktif mengembangkan potensi dirinya untuk memiliki kekuatan spiritual keagamaan, pengendalian diri, kepribadian, kecerdasan, akhlak mulia serta ketrampilan yang diperlukan dirinya, masyarakat, bangsa dan negara (Hasbullah, 2003).

Sekolah sebagai salah satu lembaga pendidikan formal yang berfungsi merealisasikan cita-cita bangsa untuk mendidik anak-anak manusia yang beriman, berakhlak mulia, berilmu pengetahuan dan menguasai tekhnologi. Sebagai institusi formal sekolah mempersiapkan siswa untuk dapat memecahkan masalah kehidupan masa kini dan masa datang, dengan memaksimalkan potensi-potensi yang ada dalam dirinya.

Pendidikan Agama khususnya agama Islam merupakan salah satu mata pelajaran pokok yang harus diajarkan di setiap jenjang pendidikan, termasuk pada SMA/MA. Sejarah Kebuyaan Islam di SMA/MA bertujuan untuk menanamkan akidah agar menjadi manusia yang bersyukur sebagai makhluk Tuhan, manusia yang rajin, giat, ulet dan disiplin dalam berusaha untuk kesejahteraan hidupnya di dunia dan di akhirat.

Sekolah sebagai salah satu lembaga pendidikan formal yang berfungsi merealisasikan cita-cita bangsa untuk mendidik anak-anak manusia yang beriman, berakhlak mulia, berilmu pengetahuan dan menguasai tekhnologi. Sekolah wajib menyelenggarakan proses belajar mengajar yang baik, dengan memperhatikan berbagai faktor penunjang. Salah satunya adalah pemanfaatan teknologi internet pada bidang penyelenggaraan pendidikan untuk pembelajaran secara daring (e-learning). 
Perkembangan teknologi menjadikan manusia untuk melakukan rekontruksi pemikiran ideal terhadap dampak positif adanya teknologi. pada era globalisasi, dampak positif teknologi yang masuk ke kehidupan manusia mampu memberikan manfaat untuk membantu mempermudah pekerjaan maupun aktifitas. Salah satunya adalah pemanfaatan teknologi internet pada bidang penyelenggaraan pendidikan untuk pembelajaran secara daring ( $e$ learning), maka dari itu konsepsi penyelenggaraan pembelajaran telah bergeser pada upaya perwujudan pembelajaran yang modern. Produk TI (Teknologi Informasi) telah memberikan alternatif berupa bahan belajar yang dapat digunakan dan dapat diakses oleh peserta didik dalam bentuk CD, DVD, Flashdisk, dan sebagainya (Darmawan, 2012).

Menurut Darin E. Hartley, "e-learning merupakan suatu jenis belajar mengajar yang memungkinkan tersampaikannya bahan ajar ke siswa dengan menggunakan media internet atau media jaringan komputer lain". E-Learning adalah sistem pembelajaran yang memanfaatkan media elektronik sebagai alat untuk membantu kegiatan pembelajaran (Daryanto, 2016). E-Learning adalah sistem pembelajaran yang memanfaatkan media elektronik sebagai alat untuk membantu kegiatan pembelajaran (Daryanto, 2016). Siswa tidak perlu duduk didalam kelas untuk menyimak setiap materi pembelajaran yang disampaikan guru secara langsung, tetapi dapat disimak setiap saat pada tempat dimana saja yang terhubung dengan fasilitas internet.

Untuk menerapkan E-Learning, minimal ada tiga komponen pembentuk E-Learning, yaitu: (1) Infrastruktur E-Learning, yaitu dapat berupa personal komputer, hp, internet dan perlengkapan multimedia lainnya, (2) Sistem dan aplikasi E-Learning, yaitu sistem perangkat lunak yang memvirtualisasi proses belajar mengajar konvensional yang meliputi bagaimana manajemen kelas, pembuatan materi atau konten, forum diskusi, sistem penilaian, sistem ujian dan segala fitur yang berhubungan dengan manajemen proses belajar mengajar, (3) Konten E-Learning, yaitu konten dan bahan ajar yang ada pada E-Learning sistem (Learning Management System).

Pembelajaran interaktif berbasis e-learning belum banyak dilakukan oleh para guru Sejarah Kebuyaan Islam (PAI) yang ada di madrasah-madrasah maupun sekolah umum, khususnya MA NU Gesi Sragen. Hal ini dikarenakan kurangnya fasilitas yang dimiliki oleh madrasah atau sekolah. Penyebab lain yaitu guru kurang antusias menggunakan media internet, dikarenakan beberapa permasalahan diantaranya belum bisa menggunakan internet atau menganggap hal yang terlalu banyak dampak negatifnya dibandingkan dampak positifnya.

Dalam perspektif agama Islam, belajar merupakan hal yang wajib dan 
keharusan untuk menuntut ilmu pengetahuan semampu dan sebanyakbanyaknya agar dapat meningkatkan derajat dan kewibawaan pada dirinya. Hal ini dinyatakan dalam al-Quran Surat Al Mujadalah ayat 11 yang artinya: "niscaya Allah akan meninggikan orang-orang yang beriman di antaramu dan orang-orang yang diberi ilmu pengetahuan beberapa derajat. dan Allah Maha mengetahui apa yang kamu kerjakan"(Direktorat Urusan Agama Islam, 2012).

Menurut Mulyono Abdurahman, prestasi belajar adalah kemampuan yang diperoleh anak setelah melalui kegiatan belajar. Sedangkan menurut Keller yang dikutip oleh Muyono Abdurahman, prestasi belajar adalah prestasi aktual yang ditampilkan oleh anak melalui usaha untuk menyelesaikan tugastugas belajar (Iskandar, 2012).

Dari pengertian prestasi belajar di atas, dapat diambil kesimpulan bahwa prestasi belajar adalah hasil yang dapat dicapai oleh seseorang (siswa) setelah melakukan kegiatan belajar dalam kurun waktu tertentu yang menghasilkan perubahan-perubahan dalam pengetahuan, keterampilan, dan nilai sikap. Seorang siswa yang telah melakukan kegiatan belajar, dapat diukur prestasinya setelah melakukan kegiatan belajar tersebut dengan menggunakan suatu alat evaluasi.

Ada 2 golongan besar yang mempengaruhi prestasi belajar siswa yaitu faktor internal dan faktor eksternal, yaitu; (1) Fakor Eksernal, yaitu faktor yang berasal dari luar diri siswa seperti; (a) Lingkungan sosial (Guru, staff administrasi, teman, tetangga dan masyarakat sekitar), (b) Lingkungan nonsosial (alat-alat belajar, gedung sekolah dan letak tempat tinggal, keadaan cuaca dan waktu yang siswa untuk belajar.

Sedangkan faktor Internal, terdiri dari aspek fisiologis dan psikologis. Aspek fisiologis merpakan kondisi umum jasmani dan tegangan otot yang menandai tingkat kebugaran organ-organ tubuh dan sendi-sendinya dapat mempengaruhi semangat dan intensitas siswa dalam mengikuti pelajaran.Intelegensi siswa. Sementara itu aspek psikologis dapat dipengaruhi oleh (a) Intelegensi siswa, (b) Sikap siswa, (c) bakat siswa, (d) Minat siswa, dan (e) Motivasi siswa (Syah, 2005).

Menurut Atkinson, motivasi dijelaskan sebagai suatu tendensi seseorang untuk berbuat yang mengingat guna menghasilkan satu hasil atau lebih pengaruh. A.W Bernard memberikan pengertian motivasi sebagai fenomena yang dilibatkan dalam perangsangan tindakan kearah tujuan-tujuan tertentu yang sebelumnya kecil atau tidak ada gerakan sama sekali kearah tujuan-tujuan tertentu. Motivasi merupakan usaha memperbesar atau mengadakan gerakan untuk mencapai tujuan tertentu. Banyak sekali, bahkan sudah umum orang menyebut dengan motif untuk menunjuk mengapa 
seseorang itu berbuat sesuatu. Kata "motif" diartikan sebagai daya upaya yang mendorong seseorang untuk melakukan sesuatu. Motif dapat diartikan sebagai daya penggerak dari dalam dan didalam subjek untk melakukan aktifitasaktifitas tertentu demi mencapai suatu tujuan. Berawal dari kata motif itu, maka motivasi dapat diartikan sebagai daya penggerak yang sudah menjadi aktif. Motif menjadi aktif pada saat-saat tertentu, terutama bila kebutuhan untuk mencapai tujuan sangat dirasakan mendesak (Prawira, 2016).

Motivasi dan belajar merupakan dua hal yang saling mempengaruhi. Belajar adalah perubahan tingkah laku secara relatif permanen dan secara potensial terjadi sebagai hasil dari praktik atau pengetahuan yang dilandasi tujuan untuk mencapai tujuan tertentu. "Motivasi belajar dapat timbul karena faktor intrinsik, berupa hasrat dan keinginan berhasil dan dorongan kebutuhan belajar, harapan akan cita-cita. Sedangkan faktor ekstrinsiknya adalah adannya penghargaan, lingkungan belajar yang kondusif, dan kegiatan belajar yang menarik" (Uno, 2011).

Perlu diketahuai bahwa dalam kegiatan sehari-hari kita banyak dipengaruhi ataupun didorong oleh motivasi ekstrisik, tetapi banyak pula yang didorong oleh motivasi intrinsik, ataupun oleh keduanya tersebut. Meski demikian, yang paling baik terutama dalam hal belajar ialah motivasi intrinsik. Sehingga dalam suatu proses pembelajaran seorang guru diharapkan mampu membangkitkan semangat belajar peserta didik dengan menggunakan motivasi intrinsik, karena dengan motivasi intrinsik siswa/peserta didik itu aktif sendiri, bekerja sendiri tanpa suruhan atau paksaan orang lain (Purwanto, 2011).

Didalam kegiatan belajar mengajar peranan motivasi baik intrinsik maupun ekstrinsik sangat diperlukan. Dengan motivasi, pelajar dapat mengembangkan aktifitas dan inisiatif, dapat mengarahkan dan memlihara ketekunan dalam melakukan kegiatan belajar. Dalam kaitan itu perlu diketahui bahwa cara dan jenis menumbuhkan motivasi adalah bermacam-macam. Tetapi untuk motivasi ekstrinsik kadang-kadang tepat, dan kadang-kadang juga bisa kurang sesuai. Hal ini guru harus hati-hati dalam menumbuhkan dan memberi motivasi bagi kegiatan belajar para anak didik. Sebab mungkin maksudnya memberikan motivasi tetapi justru tidak menguntugkan perkembangan belajar siswa. Ada beberapa bentuk atau cara untuk menumbuhkan motivasi dalam kegiatan belajar mengajar yaitu: (1) Memberi angka, (2) Hadiah, (3) Saingan/kompetisi, (4) Ego-involement, (5) Memberi ulangan, (6) Mengetahui hasil, (7) Pujian, (8) Hasrat untuk belajar, (9) Minat, (10) Tujuan yang diakui (Purwanto, 2011).

Berdasarkan fakta yang ada, pendidikan Sejarah Kebudayaan Islam 
menghadapi beberapa kendala. Antara lain materi Sejarah Kebudayaan Islam lebih terfokus pada aspek kognitifnya dan minim dalam pembentukan sikap (afektif) dan keterampilan (psikomotorik). Pendidik juga kurang memberikan motivasi dan menggunakan model pembelajaran yang statis. Hal ini menyebabkan pembelajaran kurang menarik minat peserta didik dalam belajar (Arief, 2002). Untuk mencapai tujuan pendidikan pendidik perlu memberikan motivasi belajar agar siswa mecapai tujua pendidikan. Motivasi belajar sebagai suatu pendorong yang mengubah energi dalam diri seseorang ke dalam bentuk aktivitas nyata untuk mencapai tujuan tertentu (Nyayu, 2014).

\section{B. METODE PENELITIAN}

Pada penelitian ini pendekatan yang digunakan adalah pendekatan kuantitatif karena data penelitian berupa angka-angka dan dianalisis menggunakan statistik. Penelitian ini menggunakan metode eksperimen semu (quasiexperiment) dengan desain faktorial $2 \times 2$. Eksperimen dilaksanakan terhadap pembelajaran Sejarah Kebudayaan Islam.

Populasi dalam penelitian ini adalah keseluruhan siswa MA NU Gesi Sragen Tahun pelajaran 2020/2021 yang berjumlah 78 siswa. Yang Terdiri dari Siswa perempuan berjumlah 40 siswa,dan laki-laki 34 siswa. Adapun Variabel pengaruh yang dimaksud dalam penelitian ini adalah strategi pembelajaran berbasis e-learning dan motivasi belajar. Variabel terpengaruh dalam penelitian ini adalah motivasi belajar mata pelajaran Sejarah Kebudayaan Islam, diperoleh dari nilai angket yang disebarkan kepada siswa.

Metode pengumpulan data dalam penelitian ini adalah tes dan angket. Tes dilakukan untuk mengumpulkan data hasil belajar Sejarah Kebudayaan Islam, sedangkan angket digunakan untuk mendapatkan data motivasi belajar siswa. Instrumen yang digunakan adalah tes hasil belajar Sejarah Kebuyaan Islam dan angket motivasi belajar.

Dalam penelitian ini, teknik yang digunakan dalam menganalisis data adalah dengan teknik anava varians (Anava) dengan jalur (desain Faktorial $2 \times 2)$ pada taraf signifikansi $(\alpha=0,05)$. Namun sebelum dilakukan pengujian hipotesis, data hasil belajar dilakukan uji persyaratan analisis yang meliputi: uji normalitas dan uji homogentitas data. Uji normalitas terhadap distribusi data hasil belajar Sejarah Kebuyaan Islam digunakan uji Liliefors sendangkan untuk uji homogenitas digunakan uji $\mathrm{F}$ dan uji Bartlett. Selanjutnya untuk melihat apakah ada interaksi yang sama di setiap sel dilakukan uji Scheffe pada kelompok yang berbeda sedangkan jika pada kelompok yang berjumlah sama dilakukan dengan uji Tuckey. 


\section{HASIL DAN PEMBAHASAN}

Strategi pembelajaran e-learning terbukti efektif dapat meningkatkan hasil belajar Sejarah Kebudayaan Islam siswa. Hasil temuan ini menunjukkan bahwa untuk mengajarkan materi ajar Sejarah Kebudayaan Islam lebih tepat menggunakan strategi pembelajaran e-learning.

Peserta didik dalam melaksanakan pembelajaran memiliki motivasi belajar yang berbeda-beda antara satu dengan lainnya. Namun yang pasti, setiap peserta didik berkinginan untuk dapat mencapai hasil belajar yang tinggi serta serta memiliki nilai manfaat dalam kehidupannya. Karena itu, setiap peserta didik memiliki motivasi yang diarahkan dan mendorongnya untuk untuk melakukan sesuatu dengan segenap kemampuan yang ia miliki. Dengan adanya motivasi dapat menjadi daya penggerak dapat melakukan aktivitas belajarnya secara maksimal.

\section{Pengaruh Motivasi Belajar terhadap Prestasi Mata Pelajaran Sejarah Kebudayaan Islam}

Berdasarkan perhitungan anava faktorial $2 \times 2$ diperoleh Fhitung $=$ 44,63 sedangkan nilai $\mathrm{F}_{\text {tabel }}=3,928$ untuk $\mathrm{dk}(1,114)$ dan taraf nyata $=$ 0,05. ternyata nilai $F_{\text {hitung }}=44,63>F_{\text {tabel }}=3,928$ sehingga pengujian hipotesis menolak Ho dan menerima Ha. Dengan demikian dapat ditarik simpulan bahwa terdapat perbedaan hasil hasil belajar Sejarah Kebudayaan Islam siswa dengan motivasi belajar tinggi dan motivasi belajar rendah.

Dalam hal ini hasil belajar siswa dengan motivasi belajar tinggi lebih tinggi dari pada hasil belajar Sejarah Kebudayaan Islam siswa dengan motivasi belajar rendah teruji kebenarannya. Hal ini juga terlihat dari ratarata hasil belajar Sejarah Kebudayaan Islam siswa dengan motivasi belajar tinggi $(X=73,42)$ lebih tinggi dari hasil belajar Sejarah Kebudayaan Islam siswa dengan motivasi belajar rendah $(X=67,80)$.

Peserta didik dalam melaksanakan pembelajaran memiliki motivasi belajar yang berbeda-beda antara satu dengan lainnya. Namun yang pasti, setiap peserta didik berkinginan untuk dapat mencapai hasil belajar yang tinggi serta memiliki nilai manfaat dalam kehidupannya. Karena itu, setiap peserta didik memiliki motivasi yang diarahkan dan mendorongnya untuk untuk melakukan sesuatu dengan segenap kemampuan yang ia miliki. Dengan adanya motivasi dapat menjadi daya penggerak dapat melakukan aktivitas belajarnya secara maksimal.

Senada dengan uraian di atas, dalam buku Perencanaan Pengajaran Berdasarkan Pendekatan Sistem karya Oemar Hamalik mengemukakan bahwa memotivasi belajar penting artinya dalam sebuah pembelajaran, 
karena motivasi sendiri berfungsi sebagai pendorong, menggerakkan, dan mengarahkan kegiatan belajar. Karena itu, prinsip-prinsip penggerakan motivasi belajar sangat erat kaitannya dengan prinsip-prinsip belajar itu sendiri (Hamalik, 2014).

Dalam kegiatan belajar, anak memerlukan motivasi. Misalnya seorang anak yang mengikuti ujian, membutuhkan suatu informasi atau ilmu untuk mempertahankan dirinya dalam ujian, agar memperoleh hasil yang baik. Jika dalam ujian nanti anak tidak dapat menjawab, maka akan muncul motif anak akan mencontek karena ingin mempertahankan dirinya, agar tidak dimarahi oleh orangtuanya dikarenakan memperoleh nilai yang buruk dalam ujian tersebut.

\section{Pengaruh Strategi Pembelajaran Berbasis E-Learning dan Motivasi belajar Terhadap Prestasi Mata Pelajaran Sejarah Kebudayaan Islam}

Berdasarkan perhitungan anava faktorial $2 \times 2$ diperoleh $\mathrm{F}_{\text {hitung }}=15,04$ sedangkan nilai $\mathrm{F}_{\text {tabel }}=3,928$ untuk dk $(1,114)$ dan taraf nyata $=0,05$. ternyata nilai $\mathrm{F}_{\text {hitung }}=15,04>\mathrm{F}_{\text {tabel }}=3,928$ sehingga pengujian hipotesis menolak Ho dan menerima Ha. Dengan demikian dapat ditarik simpulan bahwa terdapat interaksi antara strategi pembelajaran dan motivasi belajar terhadap hasil belajar Sejarah Kebudayaan Islam teruji kebenarannya.

Pengaruh Strategi pembelajaran berbasis e-learning dan motivasi belajar terhadap prestasi mata pelajaran sejarah kebudayaan Islam Siswa MA NU Gesi Sragen tahun Pelajaran 2020/2021 terbukti efektif signifikan dapat meningkatkan hasil belajar Sejarah Kebudayaan Islam siswa. Hasil temuan ini menunjukkan bahwa distribusi skor hasil belajar Sejarah Kebudayaan Islam siswa yang diajar dengan strategi pembelajaran e-learning dan motivasi belajar tinggi.

Interaksi antara strategi pembelajaran dan motivasi belajar dalam mempengaruhi hasil belajar Sejarah Kebudayaan Islam dapat dilihat disajikan pada gambar 1 berikut: 


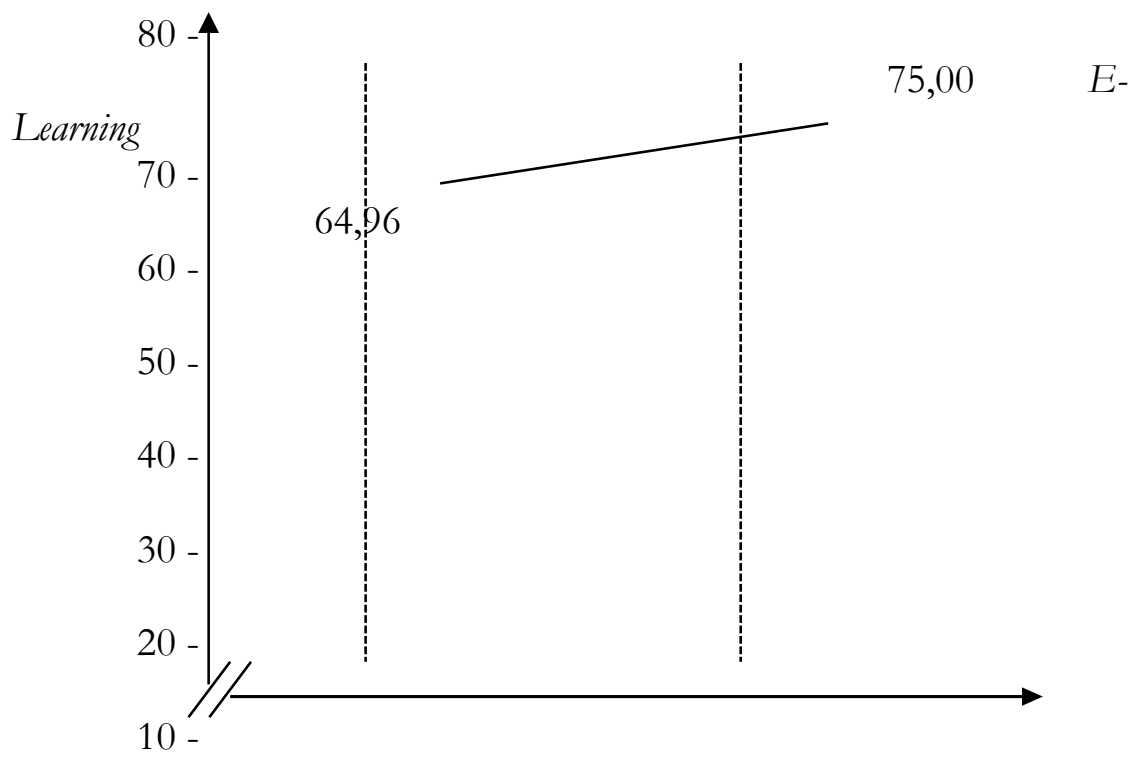

Gambar 1. Interaksi Strategi Pembelajaran Dan Motivasi Belajar

Dengan terujinya secara signifikan interaksi antara strategi pembelajaran dan motivasi belajar terhadap hasil belajar Sejarah Kebudayaan Islam, maka dilakukan uji lanjut. Sehubungan dengan jumlah sampel (n) pada setiap kelompok tidak sama, maka dilakukan uji lanjut dengan menggunakan uji Scheffe.

Berdasarkan hasil uji lanjut dengan uji Scheffe di atas maka dapat disimpulkan bahwa dari enam kombinasi pengujian lanjut maka terdapat empat pengujian uji lanjut yang menunjukkan hasil signifikan dan dua pengujian uji lanjut menunjukkan hasil yang tidak signifikan.

Hal ini dapat diinterpretasikan bahwa strategi pembelajaran e-learning terbukti efektif dapat meningkatkan hasil belajar Sejarah Kebudayaan Islam siswa. Hasil temuan ini menunjukkan bahwa untuk mengajarkan materi ajar Sejarah Kebudayaan Islam lebih tepat menggunakan strategi pembelajaran e-learning. Sejalan dengan uraian di atas, dalam buku Inovasi Pendidikan Pendekatan Praktik Teknologi Multimedia dan Pembelajaran Online karya Deni Darmawan, mengemukakan bahwa:

Program pembelajaran interaktif berbasis e-learning mampu mengaktifkan siswa untuk belajar dengan motivasi yang tinggi karena ketertarikannya pada sistem multimedia yang mampu menyuguhkan 
tampilan teks, gambar, video, sound, dan animasi.Selain itu adanya media internet memudahkan warga belajar untuk mengakses ke berbagai sumber informasi, termasuk halaman web. Melalui halaman web ini, maka warga belajar dapat mentransformasikan informasinya kepada orang lain sehingga membentuk suatu jaringan atau komunitas belajar yang dikenal dengan virtual learning atau e-learning (Hamalik, 2014).

\section{Pengaruh Strategi Pembelajaran E-Learning dan Motivasi Belajar terhadap Prestasi Mata Pelajaran Sejarah Kebudayaan Islam}

Data hasil belajar Sejarah Kebudayaan Islam siswa yang diajar dengan strategi pembelajaran e-learning dan motivasi belajar tinggi memperoleh rata-rata atau mean $=75,00$, varians $=9,93$ dan simpangan baku $=3,15$. Skor tertinggi yang diperoleh adalah 80 dan skor terendah adalah 70 . Sedangkan modus $=74,48$ dan median $=75,20$.

Distribusi skor hasil belajar Sejarah Kebudayaan Islam siswa yang diajar dengan strategi pembelajaran e-learning dan motivasi belajar tinggi disajikan pada Tabel 4 sebagai berikut:

Tabel 4. Deskripsi data hasil belajar Sejarah Kebudayaan Islam siswa yang diajar dengan strategi pembelajaran e-learning dan motivasi belajar tinggi

\begin{tabular}{|c|c|c|}
\hline Kelas Interval & $\mathbf{F}_{\text {Absolut }}$ & $\mathbf{f}_{\text {Relatif }}$ \\
\hline $70-72$ & 6 & 20,00 \\
\hline $73-75$ & 10 & 33,33 \\
\hline $76-78$ & 8 & 26,67 \\
\hline $79-81$ & 6 & 20,00 \\
\hline Jumlah & 30 & 100 \\
\hline
\end{tabular}

Berdasarkan data pada Tabel 4, maka dengan rata-rata 75,00 berada pada kelas interval 73 - 75. Dengan demikian dapat dipahami bahwa terdapat 33,33\% siswa berada pada kemampuan rata-rata kelas, sedangkan kemampuan di atas rata-rata kelas sebesar 46,67\% dan kemampuan di bawah rata-rata kelas adalah 20,00\%.

Hasil belajar Sejarah Kebudayaan Islam siswa yang diajar dengan strategi pembelajaran e-learning dan motivasi belajar rendah memperoleh rata-rata atau mean $=64,92$, varians $=7,75$ dan simpangan baku $=2,78$. Skor tertinggi yang diperoleh adalah 70 dan skor terendah adalah 60 . 
Sedangkan modus $=66,10$ dan median $=65,12$.

Uji normalitas data hasil belajar Sejarah Kebudayaan Islam siswa yang diajar dengan strategi pembelajaran e-learning dan motivasi belajar tinggi diperoleh nilai Lilliefors hitung 0,1511 sedangkan nilai Lilliefors tabel 0,1610 pada $=0,05$ dengan $\mathbf{N}=30$. Dengan demikian maka diketahui bahwa nilai Lilliefors hitung lebih kecil dari nilai Lilliefors tabel yaitu 0,1511 $<0,1610$ maka disimpulkan bahwa data hasil belajar Sejarah Kebudayaan Islam siswa yang diajar dengan strategi pembelajaran e-learning dan motivasi belajar tinggi berdistribusi normal.

Uji normalitas data hasil belajar Sejarah Kebudayaan Islam siswa yang diajar dengan strategi pembelajaran e-learning dan motivasi belajar rendah diperoleh nilai Lilliefors hitung 0,1618 sedangkan nilai Lilliefors tabel 0,1706 pada $=0,05$ dengan $\mathbf{N}=26$. Dengan demikian maka diketahui bahwa nilai Lilliefors hitung lebih kecil dari nilai Lilliefors tabel yaitu 0,1618 $<$ 0,1706 maka disimpulkan data hasil belajar Sejarah Kebudayaan Islam siswa yang diajar dengan strategi pembelajaran e-learning dan motivasi belajar rendah berdistribusi normal.

\section{KESIMPULAN}

Berdasarkan hasil analisis data dan pembahasan pada bab sebelumnya, maka diperoleh kesimpulan sebagai berikut:

1. Pengaruh Strategi pembelajaran berbasis e-learning terhadap prestasi mata pelajaran sejarah kebudayaan Islam Siswa MA NU Gesi sragen tahun Pelajaran 2020/2021. Strategi pembelajaran e-learning terbukti efektif signifikan dapat meningkatkan hasil belajar Sejarah Kebudayaan Islam Siswa.

2. Pengaruh Motivasi belajar terhadap prestasi mata pelajaran sejarah kebudayaan Islam Siswa MA NU Gesi tahun Pelajaran 2020/2021. Memberi motivasi belajar terbukti efektif signifikan dapat meningkatkan hasil belajar Sejarah Kebudayaan Islam Siswa.

3. Pengaruh Strategi pembelajaran berbasis e-learning dan motivasi belajar terhadap prestasi mata pelajaran sejarah kebudayaan Islam Siswa MA NU Gesi Sragen tahun Pelajaran 2020/2021 terbukti efektif signifikan dapat meningkatkan hasil belajar Sejarah Kebudayaan Islam siswa.

Dengan demikian hipotesis yang diajukan mengatakan bahwa "Ada pengaruh positif yang signifikan antara pembelajaran berbasis e-learning dan motivasi belajar terhadap prestasi mata pelajaran Sejarah Kebudayaan Islam siswa di MA NU Gesi sragen Tahun pelajaran 2020/2021” dapat diterima. 


\section{E. REFERENSI}

Arief, A. (2002). Pengantar Ilmu dan Metodologi Pendidikan Islam. Ciputat Press.

Darmawan, D. (2012). Inovasi Pendidikan: Pendekatan Praktik Teknologi Multimedia dan Pembelajaran Online (Cet. 1). Remaja Rosdakarya.

Daryanto. (2016). Media Pembelajaran: Peranannya Sangat Penting Dalam Mencapai Tujuan Pembelajaran. Gava Media.

Direktorat Urusan Agama Islam. (2012). Al-Qur'an dan Terjemahnya. Depag RI.

Hamalik, O. (2014). Perencanaan Pengajaran Berdasarkan Pendekatan Sistem. Bumi Aksara.

Hasbullah, H. (2003). Dasar-dasar Ilmu Pendidikan. Raja Grafindo Persada.

Iskandar, I. (2012). Psikologi Pendidikan: Sebuah Orientasi Baru. Gaung Persada Press.

Nyayu, K. (2014). Psikologi Pendidikan. Rajagrafindo Persada.

Prawira, P. A. (2016). Psikologi Pendidikan dalam Perspektif Baru. Ar-Ruzz Media.

Purwanto, M. N. (2011). Psikologi Pendidikan. Remaja Rosdakarya.

Syah, M. (2005). Psikologi Pendidikan dengan Pendekatan Baru. remaja rosdakarya.

Uno, H. B. (2011). Teori Motivasi dan Pengukurannya: Analisis di Bidang Pendidikan. PT Bumi Aksara. 